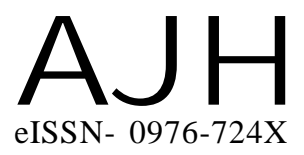

Article history :

Received : 12.05.2014

Revised : 30.10 .2014

Accepted : 12.11.2014
Members of the Research Forum

Associated Authors:

Department of Vegetable Science, Dr. Y.S. Parmar University of Horticulture and Forestry, Nauni, SOLAN (H.P.) INDIA
Author for correspondence : RAJEEV KUMAR

Department of Vegetable Science, Dr. Y.S. Parmar University of Horticulture and Forestry, Nauni, SOLAN (H.P.) INDIA

Email : rajeev3272@yahoo.com
THE ASIAN JOURNAL OF HORTICULTURE

Volume 9 | Issue 2 |Dec., 2014 |408-411

Visit us -www.researchjournal.co.in

\title{
Effect of soilless growing media, biofertilizers and fertigation levels on greenhouse tomato production
}

RAJEEV KUMAR AND MANISH K. SHARMA ${ }^{1}$

ABSTRACT : Tomato is an important cash crop of the vegetable growers in mid hill region of the Himachal Pradesh in India. Mainly the crop is raised during rainy season and the produce fetches offseason prices because of non availability of tomatoes in the markets of neighboring states which are comparatively plain areas and are not fit for growing tomatoes during rainy season. But the outdoor production of tomato faces many biotic and abiotic hurdles due to the coincidence of monsoon season with tomato fruit production. Major constraint is high rainfall coupled with high relative humidity favoring occurrence of many diseases and insect-pest attack which severely reduces the productivity and quality of the tomato fruits and growers do not get premium prices for their produce in spite of offseasonality. Hence, the only viable alternative is to grow tomato under protected conditions. The climate of the mid hills also favours for its cost effective production due to the use of low cost plastic greenhouses with natural ventilation. Therefore, a study was conducted to standardize different soil less and soil based growing media along with biofertilizers and fertigation levels for growing tomato (Solanum lycopersicum L. cv NAVEEN $2 \mathrm{~K}+$ ) in plastic greenhouses for higher productivity per unit area and superior quality of the produce during 2008 and 2009. The results comparing different treatment combinations, gave useful indication on the possibility of increasing yield, quality and component traits and decreasing occurrence of soil born diseases by using soil less growing media (Vermicompost: sand; 2:1) along with seedling treatment of Azotobacter and fertigation dose of $300 \mathrm{~kg}$ NPK per ha.

KEY WORDS : Tomato, Soilless growing media, Biofertilizers, Fertigation, Greenhouse

HOW TO CITE THIS ARTICLE : Kumar, Rajeev and Sharma, Manish K. (2014). Effect of soilless growing media, biofertilizers and fertigation levels on greenhouse tomato production. Asian J. Hort., 9(2) : 408-411. 